\title{
„Je to hra, v níž každý váš pohyb je v centru silového pole..."’ O kapilarności władzy w powieści Lehni, bestie! J. Kratochvila
}

\begin{abstract}
Balcerzak Małgorzata, ,Je to hra, v niž každý váš pohyb je v centru silového pole...”. O kapilarności władzy w powieści „Lehni, bestie!” J. Kratochvila (,Je to hra, v níž každý váš pohyb je v centru silového pole...”. The Capillarity of Power in the Novel Lehni, bestie! of J. Kratochvil). „Poznańskie Studia Slawistyczne” 5. Poznań 2013. Adam Mickiewicz University Press, pp. 19-30. ISBN 978-83-232-2636-9. ISSN 2084-3011.

This article is a critical analysis of the discourse of power represented in the postmodern narrative. In this perspective, the Czech writer's book creates a special study of the 'genealogy of power' (in relation to the concept of Michel Foucault). It arises from the combination (by using of the social-fiction literary convention) that regards the story of two symbolic forms of violence, supporting 'sacred' process of 'subjugation' of the entity (the past regime and, as result of trauma, the present and the future regime). The first form is a result of disciplinary authority of the communist system (a reference to the history of the Czech history - the period of the radicalization of the regime in the 50s of the twentieth century). The second one exemplifies the postmodern capillary violence (a reference to the terrorist attack on the World Trade Center). In this analysis, the impact of the power dissipated in the human consciousness resembles chess game, used in the story of Kratochvil in order to express a dramatic situation in which the rate is the annexation of subjectivity.
\end{abstract}

Keywords: Jiří Kratochvil; Czech literature vs. problem of power; disciplinary power; subjugation; power as a game; power and death; identity

Zločinec se octne ve vězení se dvěma východy, jeden vede na svobodu a druhý na popraviště. Prezident se rozhodne dát zločinci milost, ale ten musí uhodnout, kterým východem se dostane na svobodu. Když vyjde na popraviště, bude ihned st'at. U každého východu stojí dveřník a vězen se smí jen jednoho z nich a jen jedenkrát zeptat. Na co se zeptá, když ví, že jeden z dveřníků mluví vždy pravdu a druhý vždy lže, ale neví, který je provdomluvný a který lhář? (Kratochvil 2002: 23). 
O rozwiązanie tej łamigłówki zostaje poproszony trzynastoletni bohater powieści Lehni, bestie! Jiř́́ego Kratochvila. To jeden z „,momentów granicznych"1 w jego historii - na początku lat 50. XX wieku do brneńskiej szkoły wkracza sekretarz wraz z ,generałówką-samicą", rozpoczynając wojskową musztrę mającą na celu przegrupowanie uczniów i wyselekcjonowanie spośród nich najlepszego materiału zapewniającego powodzenie tajnej misji. Przed dotarciem do opisu jej operacyjnego szkieletu, czytelnik znajduje na pierwszej stronie następujący cytat: „Jest rzeczą równie rozsądną ukazać jakiś rodzaj uwięzienia przez inny, jak ukazać coś, co istnieje rzeczywiście, przez coś innego, co nie istnieje" - Daniel Defoe ${ }^{2}$ (Kratochvil 2002: 7). Zanim bohater zdoła uświadomić sobie doniosłość tego epizodu, udziela prawidłowej odpowiedzi na postawione pytanie, rozpoczynając tym samym cykliczną serię spotkań ze swoim Arcymistrzem przy partii szachów. Dopóki nie wybrzmi jego apokaliptyczna mowa końcowa, stanie się elementem powtórnej „dziecięcej krucjaty”; fragmentem scalającym plan, efektownego w swej wymowie, potwierdzenia normatywnej władzy systemu politycznego, przy jednoczesnym wstrząśnięciu zachodnią opinią publiczną ${ }^{3}$.

Dobrowolne poddaństwo, które Michel Foucault nazywa „rdzeniem władzy", tworzy w obrębie jej stosunków specyficzny układ relacji, który w połączeniu z wolnością daje związek ,agonalny” (Foucault 1993: 187). Weberowska definicja władzy, określająca ją jako „szansę przeprowadzenia swej woli, także wbrew oporowi" (Weber 2005: 470-492), oddaje w znacznym stopniu zawartą w niej pewną ontyczną subtelność - wyraża się ona, podobnie jak u Foucaulta (choć nie w jednakowych proporcjach), w samej możliwości, a ta bywa źródłem nieograniczonej kontroli.

\footnotetext{
${ }^{1}$ Kratochvil w artykule włączonym w część publicystycznej dyskusji na temat zmian czeskiej estetyki literackiej po 1989 roku posługuje się pojęciem „sytuacji granicznej” dla oznaczenia rdzenia narracji zindywidualizowanej, osadzonej w ramach historycznego doświadczenia (J. Kratochvil 1993: 5).

${ }^{2}$ Pisarz zaczerpnął motto z Dziennika roku zarazy Daniela Defoe (D. Defoe, Dziennik roku zarazy, przeł. J. Dmochowska, Warszawa 1959).

${ }^{3}$ Wykorzystanie quasi-dziecięcej narracji w połączeniu z konwencją powieści z gatunku social lub political fiction to zabieg stosowany również przez innego czeskiego pisarza Jachýma Topola w postmodernistycznej Strefie cyrkowej, opowiadającej o rażących skutkach politycznej indoktrynacji.
} 
Bohater Lehni, bestie! jako dziecko wychowujące się w dobie komunistycznego reżimu, kiedy nauka sprowadzana jest do haseł utwierdzających jedność autorytetu, staje się idealnym materiałem do przeprowadzenia eksperymentalnego planu, przy użyciu odpowiednich środków symbolicznej przemocy, na tyle wymownego, aby sam władzę, która namaszcza go niczym „wybrańca”, uczynił sacrum. Żonglując konwencją political fiction, Kratochvil traumę przekuwa w opowieść o procesie „ujarzmiania”4 (Foucault 2006), przy zerwaniu z klasyczną regułą suwerenności władzy obecności widzialnych insygniów, zapewniających jej trwałość. Władza, która przestaje tylko zasadzać się na fizycznym autorytecie, rozpływająca się w przestrzeni historycznych animozji, staje się sieciową relacją opatrzoną w subtelne mechanizmy wywierania wpływu, przy czym nie traci swej „boskości”. Na tym tle Lehni, bestie! odczytać można jako swoistą parabolę, układającą się w studium genealogii władzy, w której kluczową rolę odgrywa ambiwalencja śmierci (jednoczesna jej sakralizacja i profanacja), rozumiana nie tylko jako rodzaj niewytłumaczalnej ofiary, ale także metafora wewnętrznego zniewolenia, przy zaniku jej „wydarzeniowości” w świecie, w którym kategorie rozpadu i końca podlegają nieustannemu multiplikowaniu. Takie ujęcie władzy wynika z co najmniej dwóch konsekwencji: badania jej kapilarności ${ }^{5} \mathrm{w}$ procesie szczególnej implozji w ramach codziennych praktyk - trop Foucaulta i Baudrillarda (Foucault 2006; Baudrillard 2005) oraz zerwania z iluzją suwerennej formy przemocy, pojmowanej jako wynik wojny - trop Derridy (Derrida 2012).

W powieści wyróżnić można etapy ucieleśniające zmienne oblicza systemowej władzy, zapewniające powodzenie „misji samodyscyplinującej”. Pierwszym z nich jest okres edukacji szkolnej bohatera, przypadający na erę stalinizmu. Brneńska szkoła, do której uczęszcza, przypomina raczej wojskowy poligon aniżeli instytucję oświatową. Stały rytm opisywanej codzienności wyznaczają deklamowane frazy, okraszone metaforami rewolucji, podniosłe wiersze, wyrażające ,naturalne” przywiązanie do systemu

\footnotetext{
${ }^{4}$ W koncepcji władzy dyscyplinarnej Foucaulta - assujettissement.

${ }^{5}$ Owa kapilarność zasadza się na subtelnych mechanizmach władzy - jej włoskowatości i rozproszeniu, przez co traci postać wyraźnego ośrodka nacisku, stając się nieskończoną siecią niewidocznych, pozostających w ciąłym ruchu sił, podlegających ucieleśnieniu. To władza, która „w rzeczywistości produkuje realność, produkuje dziedziny przedmiotowe i rytuały prawdy" (Foucault 1993: 189).
} 
(uczniowie recytują znaczący tekst Jana Nerudy Jen dál!): „Z bouřného času jsme se narodili a krok za krokem $\mathrm{v}$ bouřných mračnech jdem vstříc hrdě vznešenému svému cíli, š́j kolníce jen před svým narodem..." (Kratochvil 2002: 19).

Sytuację zaostrza przybycie do szkoły specjalnej jednostki wojskowej. Podtrzymując wyobrażenie uczniów o wykazywaniu stałej gotowości do wcielania rewolucyjnych ideałów w życie, aranżuje ona selekcję osób zdolnych do poniesienia ofiary w politycznej misji. Wyjściowy proces stygmatyzacji podporządkowanych - oznaczenie czoła symbolem koła lub trójkąta - ufundowany jest na zakorzenionej w uczniach potrzebie nobilitacji. Bohater, znajdujący się w grupie wybrańców, zaczyna z czasem pielęgnować poczucie swej wyjątkowości i służby, mimo że nie zna celu narzuconego zadania. Etap ten wieńczy rozwiązanie wspomnianej zagadki, co, w przekonaniu bohatera, otwiera drzwi do lepszej rzeczywistości. Wrażenie szczególnego posłannictwa podtrzymują osoby odgrywające w tym przedsięwzięciu rolę dobrego policjanta. Opowiadają oni chłopcu o bar micwie, aby ostatecznie wyretuszować jego charakter, odpowiednio ukierunkowując linię priorytetów: „Ted' pravě prožíváš nejdůležitější rok svého života, ted' se rozhodne, co budeš: obyčejnskej buran, co projde životem a vủbec nic nepochopí, anebo sáhneš, po čemsi, o čem většina lidí ani netuší, že to egzystuje" (Kratochvil 2002: 32).

Pozorna w swej wymowie inicjacja widziana oczami trzynastoletniego chłopca, dla którego posłannictwo wiąże się z możliwością potwierdzenia własnej nieprzeciętności, nie ma w rzeczywistości z zaspokajaniem indywidualnych aspiracji wiele wspólnego. Bohater wkracza w kolejną fazę przygotowawcza, uzależniając swoje działanie od władzy autorytetu zdolnego utrzymać jego wyobrażenie o byciu „synem przykazania”. Pragnienie to zaspokaja Arcymistrz, reżyser spektakularnej krucjaty dzieci umieszczonych w odizolowanym miejscu przypominającym podziemny klasztor. Ich ofiara ma być najwyższym wyrazem wieczności systemu.

Foucault wskazuje na zasadniczą funkcjonalność aranżacji przestrzeni w petryfikacji władzy dyscyplinarnej, którą wyróżniać ma trójstopniowa (antydezercyjna, antywłóczęgowska, antyaglomeracyjna) taktyka (Foucault 1993: 171). W instytucjach totalnych, stanowiących naczelny obiekt analizy autora Nadzorować i karać, punktem odniesienia do poczucia podległości jest proces „dekompozycji kolektywnych lokalizacji” (Foucault 1993: 
170). W powieści Kratochvila Studnia (bo tak narrator nazywa miejsce przygotowań do samobójczej akcji) stanowi przestrzeń symptomatyczną dla zorganizowanej kontroli opartej na subtelnych mechanizmach nacisku. Władza utrzymująca w kleszczach nastoletnich bojowników, którzy mają oddać życie w celu potwierdzenia niezawisłości systemu, staje się grą utrwalaną w semiotyce przestrzennej, a przez to odbywającą się w procesach kognitywnych, przy zastosowaniu określonego kodu architektonicznego. W powieści Kratochvila tworzy go perspektywa widzenia i wpisana w nią opozycja (mrok - światło), niejako na wzór panoptycznego uniwersum: „Władza dyscyplinarna działa niewidzialnie, narzuca za to zasadę obowiązkowej widzialności tym, nad którymi jest sprawowana. W ramach dyscypliny ma być widoczne subordynowane ,ja". Jego oświetlenie jest warunkiem sprawowania nad nim władzy" (Foucault 1993: 225).

Jednym z elementów standaryzujących trwałość panowania tradycyjnego jest jego widzialność - suweren musi być czytelnym, namacalnym komunikatem dla tych, którzy mu podlegają. Władza kapilarna opiera się na zgoła odmiennej zasadzie - jej naczelny atrybut wyznacza nie-widzialność, bowiem tylko w ten sposób może prawdziwie „dobrowolnie” ujarzmiać (Foucault 1993: 225). W początkowej fazie pobytu w odosobnieniu bohater powieści utrzymuje w swej świadomości status więźnia. Perspektywę wypełnia ciemność i milczenie - główne rejestry niepewności oraz strachu przed tym, co nieznane - sugestywnie podtrzymujące przekonanie o niemożności wyjścia poza system. Znajduje się w bliżej nieokreślonym miejscu, w którym nie rozpoznaje przedmiotów, nie słyszy wyraźnych dźwięków, pomocnych w identyfikacji położenia: „Tma. Dlouho jenom tma. Ležel jsem v té tmě a bál se pohnout, protože jsem nevěděl, co se mnou je a kde to jsem. Pumpoval jsem víčkama nahoru dolů, ale ta tma byla ke mně pririrostlá" (Kratochvil 2002: 39).

Mrok i cisza, burzące praktykę dnia codziennego, pojmowane jako narzędzia podporządkowania w obliczu obcości miejsca i niemożności jego zbadania, zostaja jednak ( $w$ przekonaniu bohatera) zamienione $\mathrm{w}$ instrumenty gry o sumie zerowej, w której próbuje ocalić swą podmiotowość. Dostrzeżona przez niego smuga światła staje się jednocześnie punktem zmiany perspektywy spojrzenia, a przez to inicjuje przekształcenie topografii. Foucault wspomina, że dyscyplina „to sztuka rangi i technika zmiennej aranżacji” (Foucault 1993: 171). Celem tej gry jest nie tyle 
namacalne „trwałe osadzenie”, ile „dystrybucja ciała i włączenie go do obiegu w pewnej sieci relacji” (Foucault 1993: 171). Dynamika władzy widoczna w powieści podobnie układa się w dialektyczny układ skrywający arbitralność poddaństwa bohatera. Kiedy tylko zaczyna interpretować swoją sytuację w kontekście założonej gry, sprawdzającej jego techniczne i logiczne umiejętności, zmienia wyobrażenie o własnym położeniu. Wypełniona mrokiem więzienna cela przekształca się w miejsce iluminacji, które bohater opatrzył nazwą ,poczekalnia” dla wyrażenia transformacji swego statusu, będącego konsekwencją zwycięstwa w kolejnym etapie gry: „Takže když jsem prrišel na to, že tohle přece není vězení, taky tma tím pádem ztratila smysl a skončila. Ale přestože jsem to čekal, jakmile se dveře otevřely dokořán a místnost zaplavilo světlo $\mathrm{z}$ chodby, był to pro mě šok. A přitom to bylo světlo nedomrlé, chcípácké, takové, jaké obývá pošmourné podzimní večery" (Kratochvil 2002: 46).

Więzienie-mrok, wyrażające formułę zamknięcia, zmienia się w świetlistą scenerię, przestrzeń otwartej rozgrywki, wypełnioną efemerycznym sensem. Bohater wprawdzie dostrzega znaki cielesności władzy, która „zawsze wytwarza jakąś grę prawdy” (Błesznowski 2009: 83), jednak przyjmując czystą wiarę w swe posłannictwo, zapomina o tym, że „prawdziwe jest (dosłownie) to, co władza uznaje za prawdziwe" (Błesznowski 2009: 83). Jego metafizyczna interpretacja gry o podmiotowość stanowi jedynie produkt oddziaływania systemu, zaszczepiającego $\mathrm{w}$ nim tę wiarę. Dopiero powtórna analiza sytuacji, której Kratochvil przewrotnie nadaje formę wystąpienia przed sądem, pozwala mu zrozumieć, że rozwiązanie zagadki nie musi być jednoznaczne. Szachy stanowią prefigurację opresyjnego systemu: „Šachy jsou autismem ve dvou a zároveň modelem totalní existence, té podřízené jenom jednomu jedinému plánu, z něhož není úniku" (Kratochvil 2002: 55).

Dyscyplinarność władzy, ukonstytuowana na gruncie wiedzy (Foucault 1993), wyraża się zatem w subtelnie maskowanej nierównorzędności, która z góry deklasuje tego, kto w tym układzie sił znajduje się niżej, choć sam o tym nie wie. Podobnie rysuje się położenie bohatera powieści. Zaaranżowana przyjaźn z Arcymistrzem, pełniącym funkcję tradycyjnego mentora, wskazującego chłopcu drogę do odkrycia nadnaturalnych własności, wprowadzającego stopniowo w tajniki planu, to element wiążący jednostkę w polu widzenia władzy - w ramach strategii (w znaczeniu użytym 
przez Michela de Certeau) panowania (panoptycznej szachownicy). Boskość subtelnej władzy dyscyplinarnej wyraża się tu w mistyfikacji wolności i pośrednio wynikającego z niej przekonania o wielkości - zdolności do udziału w przedsięwzięciu, jakie wymaga niebywałej siły charakteru. Władza, jawiąca się jako szansa, jest sakralizowana na kilku płaszczyznach: po pierwsze w uzasadnieniu jej metafizyczności - wdrożeniu projektu generującego nieśmiertelność systemu poprzez symboliczną ofiarę (,nic tak nie fascynuje, jak krew niewinnych", Kratochvil 2002: 65) - stąd bierze się plan przestrzennej izolacji (przygotowań do egzaminu z wierności); po drugie w uświęceniu relacji mistrz - uczeń (przesłaniającej dychotomię kat - ofiara), przy zacieśnianiu toksycznej więzi. Cykliczne spotkania chłopca z Arcymistrzem, przybierające formułę niewinnej, intelektualnej rozrywki, służą potwierdzeniu stawki toczonej gry - dla nastoletniego bohatera jest ona siłą konieczności, w jakiej uprawomocni swoje namaszczenie (pomimo całej niedorzeczności misji), dla „dowodzącego” pozostaje niezbędnym elementem ucieleśnienia panowania i potwierdzenia racjonalności przygotowanego planu.

Nie bez znaczenia pozostaje wprowadzona w tok narracji historyczno-fikcjonalna trajektoria - zestawienie dwóch reżimów, w efekcie czego implozji ulega kategoria śmiertelności, w imię uświęcenia władzy: reżim przeszłości odnoszący się do systemu komunistycznego, sprawującego kontrolę w ramach idei klasycznego, zamkniętego Panoptykonu oraz reżim teraźniejszości i przyszłości, symptomatyczna analogia do jednej z granicznych dat w historii najnowszej (11 września 2001), według Derridy oznaczającej koniec ,archaicznego teatru przemocy” (Derrida 2012). Stanowi ona jednocześnie metaforę transformacji władzy, ujmowanej już nie jako hermetyczny system, ale wszechobecna sieć relacji. Snuta przez Kratochvila wizja fikcyjnego zamachu z udziałem dzieci, wychowywanych na podstawie fundamentalistycznej idei, uzasadniającej wymóg ofiary (akt zbiorowego samobójstwa, oczyszczając rzeczywistość społeczną, niesie tak naprawdę ze sobą najdobitniejszy znak opresyjności władzy), wyraża ambiwalencję symbolicznej przemocy, dla której szczególną matrycą jest „nieśmiertelność” (Bauman 1996: 183-202). Sygnalizuje ona możliwość wzięcia udziału w tworzeniu historii, nawet jeśli z zewnątrz interwencja ta przypomina Herostratesową sławę, odczytywaną jako skrajny akt barbarzyństwa; wewnątrz pozostaje czynem bohaterskim, dowodem koniecz- 
ności poniesienia ofiary. Stąd też mali bohaterowie powieści, będący narzędziami (i gwarantami realizacji) planu, określani są męczennikami (nie fanatykami), w ten sposób bowiem zostają uświęceni nie tylko ideowo, ale także na mocy języka, konstytuującego ich posłannictwo. W czasie inicjacji pozbywają się prawdziwych imion, przyjmując nazwiska lub przydomki zasłużonych rebeliantów, zatem ludzi mających swój udział w tworzeniu historii. Zgodnie z tą regułą główny bohater staje się Spartakusem, również jego młodsi koledzy, wzorem zakonnej formuły, przyjmują imiona takich legend, jak Róża Luksemburg, Georges Danton, Maksymilian Robespierre, Julius Fučík, Pancho Villa i in. W ten sposób, zyskując kulturowo naznaczone imię, otrzymują gwarancję wieczności w rzeczywistości, w której historia wydarza się w codzienności. Jak wskazuje Bauman:

Tworzyć historię, znaczy stawać się nieśmiertelnym; stać się nieśmiertelnym, będąc utrwalonym; być odtąd uchwyconym w zapisie, przeznaczonym do przetrwania na zawsze, niezniszczalnym; być zawsze gotowym do odkurzenia, odtworzenia, do przywrócenia porządkowi obecnego życia; mieć potwierdzoną „,ważność” dla tego życia ze względu na zmianę czy utrzymanie swej formy, swego charakteru. W uniwersum, które przetrwało jako ciąg epizodów, każde wydarzenie i każdy, kto działa, ,tworzy historię” (Bauman 1996: 215).

Zapewnienie powodzenia przygotowań i pełnej, ideowej, cielesnej akceptacji planu, to wynik przemyślanej strategii, tworzącej złudzenie posłannictwa, a przez to zaszczepiającej poczucie odpowiedzialności. Nie tylko nadanie nowych imion, pojmowane jako proces duchowej transformacji, jest taktycznym elementem gry. Mali więźniowie, podobnie jak ich dozorcy, otrzymują ubranie przypominające zestaw dwóch, semantycznie dla nich naznaczonych elementów, ucieleśnień władzy - munduru i habitu. Normatywny, a przez to uświęcony wymiar ma także przyjęta zasada „ekskomuniki" nakładanej na dezerterów, którzy nie godzą się na włączenie w realizację planu, szukając ratunku w ucieczce. W tym skrywa się śmiercionośny pierwiastek gry - kto wstępuje w jej ramy, musi posiłkować się wyłącznie jej regułami, dlatego dzieci przyjmujące na siebie jarzmo absurdalnej misji są zachęcane do działania klasyczną formułą Morturi te salutant!, w przekonaniu zasadności składanej ofiary.

Druga strona figury śmierci to podwójność samounicestwienia jako produktu ujarzmienia podmiotu, oznaka fizycznego wymiaru terrory- 
stycznego aktu (który nie rozpływa się w eterze, nie ma niczego z epizodyczności śmierci), a przede wszystkim (wskazywany przez Baudrillarda) symboliczny wymiar „samobójstwa systemu”, paradoksalnie żyjącego „Z wykluczenia śmierci” (Baudrillard 2005: 19). Ucieleśniony sprzeciw wobec zachodniego uniwersum, w efekcie ubocznym, potwierdza nieusuwalność władzy (skrywanej formuły), ponieważ ,spektakl terroryzmu narzuca terror spektaklu" (Baudrillard 2005: 34), gdzie władza to nieskończona gra iluzji i deziluzji, dialektyka ofiarnictwa i barbarzyństwa. Zanik World Trade Center dla autora Symulakrów i symulacji odsłania nie tyle fascynację zamachem, ile nade wszystko jego obrazem - ,pośród innych broni systemu, które terroryści obrócili przeciwko niemu znajduje się czas rzeczywisty obrazów, ich błyskawiczna transmisja na cały świat" (Baudrillard 2005: 31). W opowieści projektowanej przez Kratochvila, tuż po tym, kiedy Arcymistrz tworzy podatny grunt do wdrożenia planu zamachu, kreuje wiernego sprzymierzeńca i przywódcę krucjaty w postaci inteligentnego nastolatka, a jednym $\mathrm{z}$ przemożnych elementów stosowanej argumentacji jest wizja chwały zakotwiczona właśnie w strumieniu obrazów zarejestrowanym za pomocą kamer telewizyjnych: „Ti, co zůstali věrni Nesmrtelnému, shánějí už ted' ty nejlepší žalobce a soudce, kteři vás odsoudí, a ty nejlepší katy, co vás popraví, a nejlepší režiséry a kameramany, co všechno zdokumentujî" (Kratochvil 2007: 92).

W grę wchodzi zatem tylko częściowo mityczna sława, będąca dla bojowników nagrodą samą w sobie, w prezentowanym projekcie nie ma mowy o obietnicy wiecznego raju, właśnie nieobecność obietnicy pozwala pomysłodawcom krucjaty dobitniej ją umotywować aktem najwyższej ofiary, w której religijny sens zastępuje ekstaza śmierci. Wyobrażenie rozkoszy cierpienia antycypuje poczucie wielkości podejmowanego czynu i pozwala na jego sakralizację, skoro gra jest nieodwołalna, a ofiara nie może być niedostrzeżona - największym zagrożeniem jest nie tyle dyskredytacja zamachu w oczach opinii publicznej (trauma i wprowadzenie w stan osłupienia są elementami operacyjnymi projektu), ile brak jej reakcji. Takie uzasadnienie stanowi znak obowiązywania reguły telegeniczności w rzeczywistości homo videns, o której pisze Giovanni Sartori, „oczy wierzą temu, co widzą" (Sartori 2007: 41), produkując realność. Proces ten odbywa się bez udziału pośredników, zdolnych odczarować „wideopo- 
lityczną"6 grę, trwałą w wyniku nagromadzenia obrazów i ich emocjonalnej ekspansji.

Fiasko misji, wspominane z perspektywy czasu przez Spartakusa, emigranta budującego nową tożsamość pod nazwiskiem Franka Jonesa (obywatela USA, skazanego na dożywotnią psychoterapię), dotyczy tylko fizycznego wymiaru niepowodzenia planu. Narrator i więźniarka, znana jako Zoja Kosmodemianska (obecnie Carol Prerry), są jedynymi żyjącymi uczestnikami krucjaty, pozostali zginęli, zdecydowawszy się na samobójstwo, aby wypełnić obietnicę złożoną Arcymistrzowi. Los politycznego emigranta wyraża ten sam rodzaj symbolicznej śmierci, przywołując wspomniane agonalne sprzężenie wolności i władzy z ilustracji Foucaulta. Odkrycie ambiwalencji i niezawisłości symbolicznej przemocy, zmuszającej do potwierdzania i jednoczesnego dyskwalifikowania tożsamości (poprzez jej cykliczną zmianę i maskowanie), wytwarza w bohaterze przekonanie, że nie ma możliwości ucieczki, kiedy „ve skutečnosti je v nás Studna už navěky a nedokážeme ji už ničím zasypat a její otrávená voda vyrazí každou chvíli na povrch" (Kratochvil 2002: 128).

Reżim systemu wcielającego wizję szczególnego posłannictwa przy zachowaniu pozorów wolności, w ostatecznym rozrachunku prowadzi do wykorzenienia, pozbawienia tożsamości, skazując nie tylko na fizyczną banicję, ale przede wszystkim podmiotowe wykluczenie - szczególny rodzaj agonii. Jest ono produktem systemu, który podporządkowuje, wyzwalając wewnętrzną sprzeczność (bycie jednocześnie bohaterem i wrogiem rewolucji): „Ve Studni jsme byli vycepováni jako fanatičtí stoupenci revolučních idejí, ale zároven jako jejich nepřátele. Měli jsme se ztotožnit se jmény svatých mučedníků revolucí, ale zaroveň jsme se v každodenních exerciciích obviňovali z nenávisti k revoluci” (Kratochvil 2002: 128).

Jako człowiek z nową tożsamością, zapisaną w paszporcie pod nazwiskiem Jones, bohater postanawia znaleźć Arcymistrza, aby dokończyć przerwaną partię szachów, jednocześnie unicestwiając fatalną więź, ujarzmiająca jego podmiotowość. Ostateczne starcie kończy się symbolicznym zwrotem „leż, bestio!”, niedokonaną zemstą na systemie, który zawłaszczył wolność, projektowaną egzekucją. Bohater odczuwa konieczność zdania sprawy przed wyimaginowanym trybunałem sędziowskim, zakotwi-

\footnotetext{
${ }^{6} \mathrm{~W}$ znaczeniu zaproponowanym przez Sartoriego (Sartori 2007: 37-38).
} 
czonym $\mathrm{w}$ jego świadomości. Jest to jedna $\mathrm{z}$ opowieści współczesnego nomady, który senny koszmar zestawia z równie przeraźliwą, bo absurdalną i wykluczającą, systemową rzeczywistością, skazującą na życie z wydanym wyrokiem śmierci w każdym społeczno-politycznym modelu. Jednocześnie sen, będący egzemplifikacją tej śmierci, powoduje trudność rozróżnienia pomiędzy tym, co realne, a tym, co rozgrywa się w sferze wyobrażeniowej. Szczególnie w kontekście władzy, codzienność „staje się ciągłą próbą kostiumową śmierci” (Bauman 1996: 201).

Jedynym remedium, choć wątpliwym i niedoskonałym, pozostaje opowieść, w której bohater dokonuje „onirycznej egzekucji”, rozumiejąc, że władza, głęboka niczym więzienna Studnia, nie jest już czystą grą o sumie zerowej, jednoznacznym rozwiązaniem logicznej łamigłówki, ponieważ ,tytéž dveře mohou vést zaroveň i na svobodu i na popraviště” (Kratochvil 2002: 39).

\section{Literatura}

Baudrillard J., 2009, Dlaczego wszystko jeszcze nie zniknęło? Esej ostatni, przeł. S. Królak, Warszawa.

Baudrillard J., 2005, Duch terroryzmu. Requiem dla Twin Towers, przeł. R. Lis, Warszawa.

Bauman Z., 1996, Ponowoczesność, czyli dekonstruowanie nieśmiertelności, w: Postmodernizm a filozofia. Wybór tekstów, red. S. Czerniak, A. Szahaj, Warszawa, s. 183-202.

Błesznowski B., 2009, Batalia o człowieka. Genealogia władzy Michela Foucaulta jako próba wyzwolenia podmiotu, Warszawa.

Certeau Michel de, 2008, Wynaleźć codzienność. Sztuki dziatania, przeł. K. Thiel-Jańczak, Kraków, s. 30-42 i 93-110.

Defoe D., 1959, Dziennik roku zarazy, przeł. J. Dmochowska, Warszawa.

Derrida J., 2012, Co to jest terroryzm?, <http://www.nowakrytyka.pl/spip.php?article 208>, 10 grudnia.

Foucault M., 1993, Nadzorować i karać. Narodziny więzienia, przeł. T. Komendant, Warszawa.

Foucault M., 1998, Podmiot i władza, przeł. J. Zychowicz, „Lewą Nogą” nr 9, s. 174192. 
Foucault M., 2006, Trzy typy władzy, w: Wspótczesne teorie socjologiczne, wybór i oprac. A. Jasińska-Kania et al., t. 1, Warszawa, s. 512-544.

Kratochvil J., 2002, Lehni, bestie!, Praha.

Sartori G., 2007, Homo videns. Telewizja i postmyślenie, przeł. J. Uszyński, Warszawa.

Weber M., 2005, Trzy czyste typy prawomocnego panowania, przeł. B. Chwedończuk, w: Socjologia. Lektury, red. P. Sztompka, M. Kucia, Kraków, s. 470-492.

Ziętek A., 2009, Filozofia wobec 9/11. Jacques Derrida i Jurgen Habermas o terroryzmie, „Kultura i Historia”, nr 16, <http://www.kulturaihistoria.umcs.lublin.pl/arch ives/1461>, 10.12.2012.

Ziółkowski M., 1994, Sprawowanie władzy a przekonania ludzkie, „Studia Socjologiczne" nr 2, s. 55-79. 